\title{
Awareness and Utilization of Web 2.0 Technology of Young Teachers in Catholic Schools
}

\author{
Christoper Y. Jungco ${ }^{1}$ and Dennis V. Madrigal ${ }^{2}$ \\ ${ }^{1}$ St. Luke's Academy, Inc., Antique, Philippines \\ ${ }^{2}$ University of Negros Occidental-Recoletos, Bacolod City, Philippines
}

\begin{tabular}{l} 
Article history \\
Submitted: 23 October 2020 \\
Revised: 9 November 2020 \\
Accepted: 12 November 2020 \\
\hline Keywords \\
Education \\
Management \\
Web 2.0 Technology \\
Awareness \\
Utilization \\
Young Teachers \\
Descriptive-Correlational \\
Catholic School \\
Antique
\end{tabular}

Article history

Accepted: 12 November 2020

\section{Keywords}

Education

Awareness

Utilization

Descriptive-Correlational

Antique
Introduction. The development of the World Wide Web in the 1990s has brought about various technological advancements in Information and Communication Technology (ICT), which provides fast-growing web solutions (Gough, 2010). One of these web innovations is the emergence and growth of Web 2.0 technology. Web 2.0 Technology with different web sites allows users to create, generate, and share information online. However, its application has been tagged as a critical disruptive technology in education with electronic learning or e-learning (Mutula, 2013; Fleck, 2007). The emergence of Web 2.0 technology is the start of the more complicated innovation in the teaching-learning process. It is the second generation of the World Wide Web. Hence, the paper describes the level of awareness and extent of utilization of Web 2.0 technology of young teachers in Catholic Schools in Antique during the school year 2019-2020 in terms of sex and ICT training. Likewise, it explores the relationship existing between the teachers' demographics and their awareness and extent of utilization. Also, it determines the correlation among awareness and utilization of Web 2.0 technology of young teachers.

Methods. A descriptive, comparative, and correlational research design were used to assess, compare, and contrast awareness and utilization of Web 2.0 technology of young teachers in Catholic Schools during the School Year 2019-2020. Using the total enumeration, 67 teachers participated in the study. The data were gathered using a validated and reliability-tested researcher-made instrument. Mean, Standard Deviation, $\mathrm{t}$-test, and Pearson $\mathrm{r}$ were used to analyze the data.

Results. The findings of the study revealed that the level of awareness on Web 2.0 technology of young teachers in Catholic Schools is generally high regardless of sex and ICT training. Likewise. The extent of utilization of Web 2.0 technology of young teachers in Catholic Schools is moderate regardless of sex and ICT training. The findings revealed no significant difference in the level of awareness of Web 2.0 technology in ICT training. In terms of sex, findings revealed that there is a significant difference. Besides, males have a significantly higher level of Web 2.0 technology awareness than females. While when it comes to the difference in the extent of utilization of Web 2.0 technology when grouped according to sex and ICT training, findings revealed that there is no significant difference. On the other hand, there was a significant relationship between the level of Web 2.0 awareness and the extent of Web 2.0 utilization. Besides, the findings indicated that awareness significantly predicts the utilization of Web 2.0 technology.

Conclusion. The high level of awareness of Web 2.0 technology among teachers indicates that they know the different current Web 2.0 technology platforms. It signifies that teachers of Catholic schools are digital natives. However, the moderate utilization of the Web 2.0 technology signifies that teachers still need to improve in the aspect of utilization and integration of the technology in their teaching and learning activities. The overall findings imply that Web 2.0 technology education and skill training are vital factors for the teachers of Catholic schools to become adept in integrating the available digital technology in classroom instruction. 
Practical Value of the Paper. The study significantly contributes to the few existing literature on Web 2.0 awareness and utilization in Catholic schools. Also, the findings of the study provide baseline information to school administrators and teachers in formulating an Enhanced Information Communication Technology (ICT) Capability Plan for Catholic schools to enhance further the knowledge and skills of the young high school teachers in the utilization of Web 2.0.

\section{References}

Alharbi, M. (2015). Effects of Blackboard's discussion boards, blogs, and wikis on effective integration and development of literacy skills in EFL students. English Language Teaching, 8(6), 111-132.

Baro, E. E., Idiodi, E. O., \& Zaccheaus Godfrey, V. (2013). Awareness and use of Web 2.0 tools by librarians in university libraries in Nigeria. OCLC Systems \& Services: International digital library perspectives, 29(3), 170-188.

Boholano, H. (2017). Smart social networking: 21st-century teaching and learning skills. Research in Pedagogy, 7(1), 21-29.

Boulos, M. N. K., Maramba, I. 1and Steve Wheeler, S. (2006). Wikis, blogs, and podcasts: a new generation of Webbased tools for virtual collaborative clinical practice and education. BMC Medical Education 2006, 6:41

Conole, G., \& Alevizou, P. (2010). A literature review of the use of Web 2.0 tools in Higher Education. A report commissioned by the Higher Education Academy.

Fleck, J. (2007). Technology and the business school world. Journal of Management Development, 27 (4). 415-425.

Gough, J. (2010). The implications of Web 2.0 technologies are based on openness, sharing, and collaboration for professional translators and their future. Unpublished MA Dissertation, University of Surrey.

Howard, T., Cornuel, E., Thomas, M., \& Thomas, H. (2012). Using new social media and Web 2.0 technologies in business school teaching and learning. Journal of Management Development.

Mutula, S. M. (2013). The ethical dimension of social media in the information society. Innovation: journal of appropriate librarianship and information work in Southern Africa, 2013(47), 3-8.

Richardson, W. (2010). Blogs, wikis, podcasts, and other powerful web tools for classrooms. Corwin press.

\section{Correspondence:}

Christoper Y. Jungco [jungcochristoper85@gmail.com]

https://orcid.org/0000-0001-8131-1684 